\title{
More Than Serving Food on the Table: Understanding Household Relations of a Woman as a Factory Worker
}

\author{
Franceline Anggia \\ Alumni Departemen Antropologi, Universitas Gadjah Mada \\ Email: franceline.anggia@mail.ugm.ac.id
}

\begin{abstract}
Western modern theorists have long perceived intimate relations as unproductive, irrational, and unrelated to the economy. This kind of approach neglects nuanced ties that might be preconditions of women's participation in the paid workforce. Consequently, women workers' perspectives in defining their work have often been overlooked. This study will critically examine an industrial woman worker's way of defining work-decision by exploring how a desire to maintain intimate relations in the household serves as a crucial precondition for women's participation in the paid workforce. Though precariousness pervades a woman worker's work condition, a chance to work as a factory worker also becomes a source of self-esteem and selfconfidence. This study shows how nuanced and intimate relations within a household which involve performative acts of gender as a mother and a wife constitute a woman worker's insistence on working in a precarious condition. This research departs from an ethnographic-based approach relying on participant observation and in-depth interviews with a textile factory woman worker in Yogyakarta. Data analyses are processed based on thematic interpretation of field notes, transcript of the interview, and review of relevant literature regarding feminist theoretical understandings of the economy.
\end{abstract}

Keywords: women manufacturing workers, precariousness, gender performativity, intimate economy, relational autonomy

\begin{abstract}
Abstrak
Para ahli teori modernisme Barat telah lama menganggap relasi-relasi yang intim dalam rumah tangga sebagai domain yang tidak produktif, irasional, sehingga dianggap tidak ada kaitannya dengan ranah ekonomi. Cara pandang tersebut mengabaikan relasi-relasi intim yang berlapis dalam rumah tangga yang dapat menjadi prekondisi atas partisipasi kerja perempuan dalam kerja berbayar. Akibatnya, perspektif buruh perempuan sendiri dalam memandang partisipasi kerjanya sering diabaikan. Penelitian ini ditujukan untuk menelaah bagaimana perempuan buruh industri menerjemahkan keputusan kerja mereka dengan mengeksplorasi secara kritis bagaimana keinginan perempuan untuk mempertahankan relasi dalam rumah
\end{abstract}


tangga berfungsi sebagai prasyarat penting atas partisipasi kerja perempuan dalam ranah ekonomi. Studi ini menunjukkan meskipun menghadapi kondisi kerja yang rentan, kesempatan kerja sebagai buruh pabrik menjadi salah satu cara bagi buruh perempuan untuk memenuhi peran gender sebagai perempuan yang berumah tangga; di mana bayangan akan harga diri dan kepercayaan diri sebagai perempuan yang ideal dapat terpenuhi. Penelitian ini merupakan penelitian berbasis etnografi berlandaskan observasi partisipatoris dan wawancara mendalam dengan buruh perempuan industri tekstil di Yogyakarta. Data yang dikumpulkan kemudian dianalisis melalui interpretasi tematik terhadap catatan lapangan dan transkrip wawancara dengan didukung oleh studi literatur yang berpusat pada kerangka berpikir feminisme terhadap ekonomi.

Kata Kunci: buruh perempuan, kerentanan, performativitas gender, intimate economy, otonomi relasional

\section{Introduction}

"The economy can be a space of ethical action, not a place of submission to the "bottom line' or the 'imperatives of capital' as it is so often portrayed" (Gibson-Graham 2011, 29).

Capitalism often appears as the central orbit of economic activities assumed to be formed by a single economic logic. In hegemonic understandings of political economy, issues of industrial women workers seem inextricably linked with efforts to unravel the logic of capital accumulation that is perceived to underlie every form of industrial relations. Existing research has stressed industrial women workers as objects of exploitation and victims of capital accumulation due to women's loss of control over the means and process of production (Wolf 1988, 88). The extension of this thought can be seen through a growing number of works number of works with topics revolve around state neoliberal policies, flexible capital accumulation, market transactions, and the way production politics affects women workers' bargaining position in the workplace (Tjandraningsih 2000; Tjandraningsih 2012; Suryomenggolo 2012) as well as at the domestic realm of a household (Saptari 2000; Saptari 2008). Furthermore, women's vulnerability as industrial workers has often been perceived as the extension of systemic subordination that women already experienced in a patriarchal system of the society (Hancock 2001) outside the capitalist labour processes. Here, I argue the narratives as mentioned earlier privileged private accumulation as the main driving force of economic activities.

Taking Gibson-Graham's work into account, privileging capital accumulation or market ethics as the point of departure to explain the economy is an attitude towards "capitalocentrism," which is insufficient to understand the heterogeneity within economic landscapes (Gibson-Graham 2014, 4-5). Through the lens of capitalocentrism, capital maximization is perceived as the central orbit of economic dynamics, neglecting the more subtle and affective manners of economic practices which involve trust, care, future orientation, collective agreement, guilt, love, community pressure, and self-exploitation 
(Gibson-Graham 2014, 10). Applying the capitalocentric framework in discussing women workers risks not giving profound attention to women workers' interests along with their various socio-cultural strategies in tackling precarious life (Mundayat 2008, 2).

By challenging capitalocentric ways in discussing industrial women workers, this study sheds more light on theoretical and empirical discussions on how intimate life, notably related to gender and domestic realm of the household, fostering women's participation in the paid workforce and a woman's self-conception as a good mother and wife. The main subject of this research is women workers who are married and have children. However, I aware that women workers do not constitute a homogenous group. Rather than seeing intimate life as non-economic and non-productive, I propose to broaden the economy as a site of contestation of personal experiences in which human produce and develop creative strategies to thrive and make sense of precarious lives, which both deserve special scrutiny.

This paper is developed from the research I conducted for my undergraduate thesis. This study was carried out in 2019 (April-June) at a garment and gloves factory in Yogyakarta, where I did interviews with four women workers, a manager of the garment factory, together with members of a non-governmental organization that is dealing with workers' advocacy-related issues. In this paper, I present the story of a woman worker, named Irawati, who has been working for years in a South Korean-owned gloves factory in Yogyakarta. Irawati's story reflects how the intimate life involving her gender status as a wife and mother affects the way she perceives her labour power in the paid workforce and the experiences of precariousness she encounters on the factory floor. Though facing many difficulties on the factory floor, working as a factory worker helps Irawati to gain selfconfidence self-confidence and liven up her ideas of prosperity that she is eager to pursue.

Departing my research from an ethnographic-based approach, I contend that work participation as an industrial worker can be based on an intimate aspect and is gendered in two senses. First, gender ideology underlies the abundant number of women workers working in the textile and garment industry. It also serves as a legitimate and strategic mechanism of women workers' body discipline. Second, it is gendered since a woman's work in the formal economy presents as a constitutive element of a woman's desire to fulfil intimate kinship obligations in the domestic realm of the household. These obligations are reflected in the idea of prosperity projected by the woman to her children, showing her as the one who is responsible for realizing the well-being of other family members. Drawing from Butler's view on gender performativity, I suggest a woman's work as a factory worker can also be perceived as a site of performing gender. By giving the labour power in the paid workforce, a woman becomes a feminine subject who is activated and enabled through her struggle for realizing the well-being of family members, however hard the work condition might be in the factory.

This study shows how private accumulation does not present as the primary purpose of economic activities. Participating in the paid workforce is rather being preconditioned by complex relationships between woman workers, family members, and gender status as a mother and a wife in a heterosexual setting of the household. Therefore, working as an industrial worker is not only an economic marker, but also a process of becoming a feminine subject for the woman that I met during the research. Hence, by taking a closer look at ethnographic cases, I argue that it would be misleading to treat workers as necessarily having a direct antagonistic relationship to the industrial power constellations 
since, in practical manners, workers' experiences cannot be reduced into that binary model of thinking.

By paying closer attention to the intimate life of the woman worker, this study does not aim to leave issues concerning industrial power relations out of the discussion. Instead, this study's purpose is to find linkages between industrial and intimate relations in the domestic realm of the household. The latter has commonly been perceived to be separate and irrelevant to the debate on the politics of industrial relations. In order to unravel the linkages back into the fore, I begin the discussion of gender politics by exploring women's participation in Indonesia's garment and textile industry while linking it into the context of the state's political agendas under the military regime of President Soeharto (19661998). The discussion will be followed by a critical analysis of Irawati's experiences as a factory worker and how those experiences affect and are affected by intimate relations of the household where Irawati realizes a sense of kinship obligations. In the last section of the discussion, I will elaborate on how Irawati articulates the ideal future she has been struggling for that seems inseparable from her reproduction roles as a married woman.

\section{Discussion}

\section{Gender Politics and the Development of Garment and Textile Industry in Indonesia}

The early 1970s marked an important year for Indonesia's rapid economic growth after two decades of social and economic inferiority following the country's independence in 1945. This growth occurred before the country experienced the massive impact of the Asian financial crisis in 1997-1998 (Tambunan 2006). The regime transition of Old Order (Orde Lama) to the New Order (Orde Baru) led by President Soeharto serves as a significant part of history. President Soeharto connected the country to a new economic orientation where he promoted the industrial sector to anchor economic development. The New Order government encapsulated the planning unit known as REPELITA (Five Year Development Plan), where the economic development was pursued through some economic reform policies, such as opening up more extensive opportunities for foreign investment and international trade, which were carried out intensively from 1970 to 1980 (Tambunan 1998).

Under the Soeharto military dictatorship, the efforts to grow a national economy based on the industrial sector were carried out in two ways. First, by implementing import substitution for labor-intensive industries, for instance, textile industry, timber industry, and food and beverages industry. Second, in the 1980s, the strategy was shifted into an export-oriented enterprise, especially for non-oil and gas commodities. The garment and textile industry, which belongs to the non-oil and gas commodity, played a pivotal role in contributing to the country's domestic income. Since then, Indonesia's garment and textile industry have been set off to compete on a global level, which marked the neoliberalization of the economy pioneered by the New Order regime (Aspinall 2013). The implementation was deepened by the Asian monetary crisis in 1997. The state started to implement economic restructuring borne on competition and labour flexibility considered to be the panacea of the financial crisis (Tjandraningsih 2012).

Supported by the increased foreign capital and import restriction policies, the 
Indonesian textile and garment industry grew rapidly. As a result, national export increased along with factories relocation that previously operated in Hong Kong, South Korea, Taiwan, and Singapore to the developing countries (Tjandraningsih 2000, 259). Factory relocation was one of the strategies for enterprises to save labour costs that were much lower in developing countries. This strategy facilitated a new pattern of capital accumulation marked by flexible strategies (Ong 1991). In addition to its massive contribution to national revenue, the Indonesian garment and textile factories have been a significant source of employment, especially for women (Retyaningtyas, Widyawati, and Wusana 2017; Horne dan de Andrade 2017). In 2016, the International Labour Organization noted that women workers who work in the garment and textile industry in Indonesia outnumbered male workers in the same sector, comprising $35.5 \%$ and $19.8 \%$ of Indonesian manufacturing workers, respectively. The apparel and garment industry in Indonesia even absorbs more than 2.37 million workers, with an estimated number of women workers reaching $80 \%$ of the total.

There are socio-cultural conditions that make the vast recruitment of women workers into the garment and textile industry possible. The essentialist gender stereotypes, which assume women to have inherent characteristics such as persistence, patience, and more obedience than men, have been a common sense behind a large number of women workers recruited in labour intensive assembly operations. The tasks in the garment and textile industry such as sewing and ironing, are often associated with domestic works that women supposedly do. This issue is emphasized by Akirnadi, the Secretary General of Yogyakarta Workers Alliance (Aliansi Buruh Yogyakarta), who has much concern on issues concerning workers advocacy. He pointed out a widespread belief that women are more "naturally" suitable than men in repetitious works with a high demand for persistence, patience, and attention to detail. Those two qualities are strongly associated with women's reproductive works (interview, February 2019). The capability to work with incredible dexterity is believed to be produced by the innate capacities of women since they are having what is called "nimble fingers" (Elson and Pearson 1981).

However, the widespread belief that positions women to be more suitable for repetitious work with a high degree of order is far from natural. Elson and Pearson (1981) suggest how women's "nimble fingers" is the result of a long-term training and socialization that women have learned in their lifetime to practice the socially appropriate women's roles. However, women's manual dexterity under the heading of domestic labour is socially invisible and being privatized, thus the jobs associated with women's work are socially unrecognized and considered unskilled (Elson and Pearson 1981, 93). Consequently, women have a secondary status in the labour market and they are paid with lower wages that do not cover the reproduction costs of their labour power (Elson and Pearson 1981, 97).

Furthermore, the essentialist thinking concerning gender is often politicized to justify the systemic exploitation of women workers. For instance, Guy Standing (2011) argues that in the early globalization era (1975-2008), women were taking a growing proportion of all jobs. Standing termed it as "the feminization of labour," which serves in two senses: more women were employed and women typically took more flexible jobs. One of the factors that contributed to the feminization of labour was the demise of family wage. Due to the family wage rule being demised, more jobs and employment favoured women workers. Many 
assume that women are never expected to earn a family wage since they are considered as the secondary family earner (Standing 2011, 60). This assumption indeed fails to give special attention to various groups of women such as lower-middle-class women and single mothers who, in many cases, present as the main-if not the only-family income earner, challenging the culturally defined man as the primary family earner.

My conversation with a male factory manager in Yogyakarta illustrates an example of how gender stereotypes render women workers to be in a different degree of precariousness compared to men workers:

"Men workers are more flexible to work overtime and meet production targets. Women workers are not like that. They usually have a lot of things to do that distract their work at the factory, for example, attending her children's progress report meeting in school, attending social gatherings such as a wedding ceremony" (interview, November 2019).

Consequently, in one of two garment factories that I had visited, women are favoured to be employed as temporary workers whose wage is determined by the number of output production they complete. Temporary workers do not acquire social benefits such as paid maternity leave and healthcare benefits. On the other hand, full-time workers occupying managerial positions in the factory are predominantly male workers which animate particular gender relations in the workplace.

There is existing research focusing on gender reproduction as a part of the industrial discipline. Ong's (2010) inquiry on the establishment of the Malaysian Free Trade Zone (FTZ) shows how the Malaysian government employed various strategies to attract foreign investment and integrate Malay peasant women into industrial discipline by drawing it upon economic, political, and locally mediated cultural discourses and practices pertaining to gender inequality. The government promoted Malay women as biologically suited to do tedious work with extreme care-those considered "feminine traits" that men workers do not have. Foreign factories benefited from the low labour costs by recruiting (primarily single) young rural women that were already socialized to be diligent and obedient (Ong 2010, 153). The low labour costs are also generated by the enterprise limiting the employment of women workers due to women's "life cycle" to marry and expect children. However, the rules regulating labour and gender relations are not static. They are determined by the dynamic interplay of state policies, production systems, and the unwritten and diverse assumptions concerning womanhood and manhood within the labour markets, communities, and households" (Saptari 2000, 149). For example, a study by Arnold (2013) about Cambodia's garment production shows how Cambodian labour relations are affected and reconfigured by the changes of state development agendas and years of war in Cambodia from the late 1960s to the mid-1990s. These factors form a particular nature of workers' activism and trade unions in that country.

Gender relations are only one component of the heterogeneity that enables the industrial-based economic system to sustain itself. Workers, states, and capitalists are not the main actors that drive economic production. In the end, industrial relations are not only constituted by class relations that distance themselves from a certain historical context links to colonialism, race relations, and various forms of patriarchal relations, that shape the mobilization of capital and labour mobilization (Tsing 2009, 151). As Ong has argued elsewhere, capitalist discipline operates through overlapping networks of power relations 
regulating daily practices, norms, and attitudes that legitimize the unequal relations that sustain capitalism. States, households, religions, industrial institutions, and gender relations are deeply intertwined and constitute various experiences, work commitments, and workers' different subjectivities (Ong 1991, 286).

In this study, I would not prefer to see workers as a mere static class marker that revolves around economic production. Marx's analyses of class relations in a capitalist society which relied on a sharp opposition between the bourgeois and the working class have to be challenged again. Marx had not given profound attention to nuanced relations by not considering the economic system as a system that is never autonomous from family and kinship processes (Yanagisako 2002, 12-13). There are various actors that come to mediate and facilitate economic production who do not necessarily stand on the class dichotomy that Marx had already proposed. Therefore, I argue that there are also cultural conditions that enable individuals to have their own productive capacities to become a worker or a capitalist. In the next section, I will go into an illustration of how work commitment as an industrial worker is preconditioned by intimate relations within the domestic realm of the household.

\section{Meeting Irawati: Transgressing Domestic Space, Negotiating Power}

Having completed vocational high school in 1999, Irawati (a pseudonym) started working at PT Jogja Gloves Tunggal (hereafter JGT, a pseudonym) in 2000. PT JGT is a South Korean-owned textile product company that produces gloves, ranging from sport gloves to winter gloves exported to countries in Southeast Asia, North America, and Europe. The JGT factory has been operating in Yogyakarta since 2000. There are 700 workers working in the factory, with approximately $80 \%$ of the total workforce being made up of women. By the time of my fieldwork in 2019, it has been nearly nineteen years since Irawati started working at the factory production line.

In her daily life, Irawati starts her morning routine by washing clothes and later going to the market to buy some ingredients to cook for her husband who works as an occasional construction worker and for her two sons. Located seven kilometres away from her house, Irawati starts working at the factory at 7.30 in the morning and supposedly finishes her work at 15.15 in the afternoon. However, in practice, workers in the production line experience frequent overtime until 18.00 in order to meet production targets without receiving overtime pay. Workers in the JGT factory usually produce roughly 3,600 gloves each day, with the wage they earn falling upon the minimum wage of Sleman Regency (Upah Minimum Kabupaten Sleman) with the amount of 1.701.000.00 rupiahs (\$117) ${ }^{1}$.

As well as giving her labour-power in the production line, Irawati is an active member of the worker union in the JGT factory as a secretary. Her participation in the union becomes the modality for Irawati to examine workers' rights and know what kind of infringement the company does against the rights of its workers. For her, participation in the worker union is a strategic mechanism she employs to gain recognition from the municipal representative of the Ministry of Manpower. According to her, the government's recognition is important since it ensures her life amidst the work instability she experiences as a factory worker. In this context, Irawati articulated the instability in terms of the

1 The minimum standard of wage in Sleman Regency in 2019. 
possibility the possibility of being terminated as the company might be go bankrupt someday (interview, May 2019). This story expresses Irawati's sense of uncertainty. At the same time, her participation in the worker union can be seen as involvement in a social safety net, illustrating her creative capability to mollify risks and precariousness that she encounters at the workplace (Silvey and Elmhirst 2003).

As I follow Irawati's experiences as a factory worker, the story that she often told me was about the overtime work that she experiences almost every day. It turned out that it was not only her but also other women workers in the production line, who are mostly married and have children, who criticized the overtime work. This problem was collectively expressed in a monthly meeting of the worker union that I attended during my research. Rather than problematizing the absence of overtime pay, the women workers whom I met perceive the overtime work in the factory as the main obstacle hindering them from accomplishing domestic tasks at home. The discontent was also emphasized by Irawati herself:

"You know, that kind of thing (refering to the overtime work) disturbs the harmony of the family. My husband does not like it if I do other work while domestic work remains unresolved" (interview, March 2019, italic mine).

Irawati's statement depicts her conception of an ideal family that revolves around cooperation among family members within the heterosexualized division of labour. Within the heterosexual framework, Irawati's statement illustrates how harmony in the family is constructed through labour performances in which a discourse of natural differences between men's and women's roles in the household takes place. Irawati's conception of an ideal family presents as a key feature of how she defines her discontent in the workplace. The overtime work that hinders her to accomplish domestic work is also considered to disrupt her self-conception of a good wife, good mother, and of a feminine subject, which is activated through spending more time taking care of the husband and children at home.

In later discussion, I will show how Irawati's work "satisfaction" in the paid workforce stems from her understanding of how a woman should do in a (heterosexual) family. Departing from this point, it helps us rethink an alternative knowledge of domestic labour outside of models that perceive women as a mere group that is exploited and oppressed by their male partner in the household. It is crucial to bear in mind that there are moments of possibilities when a wide variety of gendered subjectivities outside the exploiter and exploited dichotomy may take place in the household (Cameron 1996, 26).

By giving more nuanced attention to Irawati's story, it paves the way to understand that there are possibilities where the heterosexualized configuration of desires and gender is transgressed and renegotiated through everyday lives. Additionally, Butler's work on gender as a performative activity (1988) supports my arguments. As Butler proposed, gender is not a static cultural marker or a predetermined knowledge imposed upon the sexed body; "rather the body becomes its gender through a series of acts which are renewed, revised, and consolidated through time" (Butler 1988, 523).

For Irawati, doing domestic work is her top priority as a married woman. That is why working at the factory is not ideal for her due to the overtime work that obstructs her desire to accomplish domestic work at home. As a married woman, she defines an ideal job as a job in which she can both earn money without having to sacrifice her duties at 
home. In doing so, Irawati can feel like a "real" woman (interview, December 2019). Despite giving her labour outside the home and investing much time juggling between factory and domestic works, Irawati still regards her husband as the primary family earner:

"Women like buying make-up and shoes. I am embarrassed (malu) if I ask my husband for money. At least I work to give pocket money to my children" (interview, March 2019, emphasis mine).

The embarrassment that Irawati might feel can be caused by her understanding that buying make-up and shoes are regarded as self-indulgence. It has nothing to do with the reproductive tasks she bears as a married woman who should prioritize the interest of other family members over hers. By saying, "at least I work to give pocket money to my children," represents how Irawati devalues her labour power in the paid workforce. In addition to it, the "at least" she expressed illustrates the culturally defined heterosexualized ${ }^{2}$ division of labour in which a woman is assumed to only be a secondary earner of the household. At the same time, a man serves as the main family earner and family representative to a broader society. By devaluing her labour power in the paid workforce and domesticating ${ }^{3}$ her desire, Irawati is enabled to be a feminine subject within the body of heterosexualized division of labour. Nevertheless, I was intrigued by the fact that Irawati still finds herself feeling embarrassed if she had to ask her husband for money while at the same time regarding her husband as the primary family earner.

The way Irawati devalues her labour and how she expresses embarrassment enables her husband to be a masculine subject that is activated and protected by Irawati who claims her husband as the primary family earner. What is perceived as the ideal is not always in line with practice: Irawati might have given a more significant financial contribution than her husband, whose work as a construction worker is much less stable. The less stable income is reflected through Irawati's story when she once told me that her husband gets an income only when he has a construction project to be done. There is no particular time when her husband will receive the wage-consequently, some family's basic needs, such as paying the children's tuition fee and credit loans, are paid by Irawati herself.

In other words, Irawati's control of her desires does not come out in a vacuum. The way Irawati domesticates her desires is constituted by heteronormativity that defines her idealized conception of the sexual division of labour in the household. I attempt to see the way of domesticating desire as a representation of gender performativity and how desire is also gendered. The way Irawati domesticates desires legitimizes her transgression from domestic sphere that supposedly presents as the essential sphere for crafting her sense of self. In this way, gender is thus a process of becoming that is never complete and constantly renegotiated.

\section{Defining a Better Future in Precariousness}

Women's economic prowess in the context of Javanese society is not an unfamiliar

2 This term is drawn from the work of Cameron (1996).

3 The term 'domesticates' is drawn from the work of Brenner (1998) as she suggests domesticate as the idea of bringing something under control as well as turning it into something of value to the family (p. 17). 
phenomenon. Conducting her fieldwork inquiry among the merchant community in the neighbourhood of Laweyan, Solo, Brenner (1998) demonstrates Javanese women's pivotal roles in generating material, cultural, and social values for their families by engaging in trade at the marketplace. Among the merchant community, women are "praised" for their financial skills and capability to produce wealth for the family. However, Brenner further argued that women's concern for money and their active quest for material gains ended up demeaning women's social status, opposing the far-reaching priyayi ${ }^{4}$ ideologies in which the conspicuous pursuit for money is considered coarse (kasar) and lack of cultural refinement.

Both my inquiry and Brenner's reveal how women's work is devalued. However, it is still worth recalling the different research contexts; in which Brenner did her fieldwork among the entrepreneurial community while my fieldwork was carried out among the working class. It must be kept in mind that there is a different historical context between the classes and different household dynamics engendered from it, therefore the devaluation may also take different forms.

In another case, Irawati expressed the devaluation of her work through her visions of prosperity projected to her sons, which stands in contrast with the precariousness she experiences on the factory floor:

"I want my children to have a steady (mapan) job, not just be a coolie (kuli) like me. I wish my children can be policemen or civil servants. So, their life will be much better than mine" (interview, December 2019, italic and emphasis mine).

Being a policeman or civil servant (pegawai negeri sipil or PNS) constitutes an ideal job that could pave the way to enhance living standards. These particular jobs that Irawati mentioned do not appear out of the blue. Having a job as a policeman or civil servant lent an air of professionalism and greater material stability, which expressed in sharp contrast with Irawati's precariousness as a factory worker. When someone becomes a policeman or civil servant, they might earn a relatively certain amount of wage. The state ensures their life through various types of benefits even after retirement. In this context, precarity plays as a constitutive element in defining identities (Rudnyckyj 2018) and navigating someone's sense of self-esteem. This also shows how precarious work has, in turn, created a form of social precarity that is expressed through visions of prosperity.

On the other hand, being a policeman or civil servant also serves as a "traditional" symbol of authority and "freedom", in contrast to factory workers. A policeman and civil servant are considerably at the top of a bureaucratic system, whose works are to create

4 Brenner (1998) has noted that hierarchy in Java deeply revolves around the notion of cultural refinement which is best represented by the priyayi as the class of aristocratic and bureaucratic elites. Priyayis ways of life stood as an antithesis of the merchant class. One significant distinction between the two classes is the different understanding of the source of "power". In the merchant community, money or wealth serves as significant means for generating status and it is counted as the source of power. This, however, challenged priyayi ideologies in which wealth should follow from power, not power from wealth (p. 58).

5 Although in fact, I would say that the so-called "freedom" is not necessarily the case in the bureaucratic system. A renowned German sociologist, Max Weber (1946) has suggested that hierarchical authority is in fact the basic principle of all bureaucratic structures. There are 
order. They ostensibly stood against factory workers who, to a certain degree, have to defer to a specific system of control manifested into a particular timetable that establishes rhythms and regulates the cycles of repetition (Foucault 1975, 149). As Sopranzetti (2018) pointed out that "on the factory floor, workers had to submit their bodies to the rationalized industrial discipline which impose particular occupations to the point where every hand would work in unison, reducing it into orchestrated and automated movements" (Foucault 1975, 128).

The process of submitting bodies to the rationalized system of discipline creates a sense of being controlled and supervised, which is expressed by calling Irawati herself a "coolie" (kuli): a derogatory term for an unskilled, a cheap-paid worker, who performs manual labour under a powerful and pervasive supervision that controls time and mobility of workers (Warouw 2008). I suggest the term kuli acts as a metaphor for Irawati's sense of being controlled, which hinders her capacity to reclaim time and mobility as a married woman who has responsibilities to look after her husband and children outside the factory. The sense of being controlled disturbs her self-understanding of autonomy that acquires its meaning through her relations of dependency with other family members. Here, autonomy is not drawn on an isolated, asocial, and individualistic tone but it is drawn on a claim that an individual's sense of self is closely connected to the family and community relationships they participate in (Mackenzie and Stoljar 2000, 7). In Irawati's perspective, working at the factory is therefore not an ideal occupation since it interrupts her from doing domestic obligations that supposedly serve as a key facet for crafting her sense of self as a married woman.

Moreover, we should not forget that Irawati's visions of prosperity do not stem only from her status as a married woman but also from her partaking in the worker union, looking for refuge. Given Irawati's participation in the worker union, this experience builds her self-awareness of precarity she has been dealing with for years at the factory. On the one hand, this shows how Irawati's activism in the worker union plays a significant role in forming knowledge of work precarity, which builds Irawati's particular vision of prosperity and imagined-life stability. Irawati's vision of prosperity and life stability represents how the experience of precariousness as a factory worker has, in turn, destabilized her life, notably as a married woman and a mother. This is obvious how precarity does not only revolve around work but intersects with other domains of life.

Irawati's story reminds us the way to not simply reduce the economy as a field of market transactions and wealth extraction, in which everyday people simply serve as consumers and income earners (Gibson-Graham 2013). Relations of kinship, collective reciprocity, affection, and spirituality are significant driving forces of human creativity to survive (Gibson-Graham 2014, 10). As Fraser (2016, 101-102) had puts it, capitalist economy primarily relies on social reproduction; such as the work of birthing, provisioning, caregiving, and maintaining social bonds, although they have long been accorded no monetized value as if they were free and "non-productive."

levels of graded authority in which the lower officials are supervised by the higher ones. Such compliance is therefore needed and conditioned to maintain this hierarchical-bureaucratic relationship. For further analyses, Graeber (2015) also contends how bureaucracy itself lies and is built from unequal power relations in a society. 
Reflecting on Irawati's experiences, it shows that her motivation and dissatisfaction as a factory worker and her visions of prosperity do not suggest private accumulation as the main goal of realizing her labour in the paid workforce. Instead, they are deeply rooted in the domestic setting where Irawati gains her sense of empowerment.

\section{Conclusions}

Capitalocentrism has been a fundamental way of discussing issues concerning industrial workers. In this study, I do not intend to underestimate capitalocentric ways of discussing issues of industrial workers. Instead, I aim to suggest that capitalocentric thought is not sufficient because it excludes the nuanced, subtle, and intimate relationships, which come as crucial parts underlying women's work commitment, work satisfaction and dissatisfaction, and aspirations when women participate in the paid workforce.

More than mere private accumulation, this study reveals how gender -which acquires its meaning through performative activities in the domestic realm- presents as a significant force in forming work commitment, work satisfaction, and dissatisfaction, as well as women's visions of prosperity as a factory worker and a married woman. Hence, women workers' subjectivities are crafted not only from the workplace but also from intimate relations in the household. Therefore, I argue that there is a dialectical, strongly connected relationship between the workplace and the household. A solid separation between the two would end up unproductive.

Finally, it is important to note that Irawati's story is only one representation of one representation of women workers' experiences. This study acknowledges that there are various household dynamics and different identities of women that would form diverse subjectivities even within the same status as a factory worker.

\section{References}

Arnold, D. 2013. "Workers' Agency and Re-Working Power Relations in Cambodia Garment Industry." Manchester: Capturing the Gains, The University of Manchester, (Working Paper 24).

Aspinall, E. 2013. "A Nation in Fragments: Patronage and Neoliberalism in Contemporary Indonesia." Critical Asian Studies Vol. 45 No. 1, 27-54.

Brenner, S. 1998. The Domestication of Desire: Women, Wealth, and Modernity in Java. New Jersey: Princeton University Press.

Butler, J. 1988. "Performative Acts and Gender Constitutions: An Essay in Phenomenology and Feminist Theory." Theatre Journal, Vol. 40 No. 4, 519-531.

Cameron, J. 1996. "Throwing a Dishcloth into the Works: Troubling Theories of Domestic Labor.” Rethinking Marxism Vol. 9 No.2, 25-44.

Elson, D., \& Pearson, R. 1981. "Nimble Fingers, Make Cheap Workers: An Analysis of Women's Employment in Third World Export Manufacturing." Feminist Review Vol. 4, 87-107.

Foucault, M. 1975. Discipline and Punish: The Birth of the Prison. Vintage Books: New York. Fraser, N. 2016. Contradictions of Capital and Care. New Left Review 100, 117.

Gibson-Graham, J. 2013. Take Back the Economy: An Ethical Guide for Transforming Our Communities. Minneapolis: University of Minnesota Press. 
Gibson-Graham, J. 2014. Rethinking the Economy with Thick Description and Weak Theory. Current Anthropology 59.

Gibson-Graham, J., \& Roelvink, G. 2011. The Nitty Gritty of Creating Alternative Economies. Social Alternatives, Vol. 30 No.1, 29-33.

Graeber, D. 2015. The Utopia of Rules: On Technology, Stupidity, and the Secret Joys of Bureaucracy. Brooklyn: Melville House.

Hancock, P. 2001. Rural Women Earning Income in Indonesia Factories: The Impact on Gender Relations. Gender and Development, Vol. 9 No.1, 18-24.

Horne, R., \& de Andrade, M. C. 2017. Mixed Picture for Indonesia's Garment Sector. International Labour Organization.

Mackenzie, C., \& Stoljar, N. 2000. Relational Autonomy: Feminist Perspectives on Autonomy, Agency, and the Social Self. New York: Oxford University Press.

Mundayat, A. M. 2008. Bertahan Hidup di Desa atau Tahan Hidup di Kota: Balada Buruh Perempuan. Jakarta: Women Research Institute.

Ong, A. 1991. The Gender and Labor Politics of Postmodernity. Annual Review of Anthropology, Vol. 20, 279-309.

Ong, A. 2010. The Modern Corporation: Manufacturing Gender Hierarchy. In A. Ong, Spirit of Resistance and Capitalist Discipline: Factory Women in Malaysia (pp. 141178). New York: State University of New York Press.

Retyaningtyas, W. L., Widyawati, V., \& Wusana, S. (2017). Pelecehan Seksual dan Pengabaian Hak Maternitas pada Buruh Garmen. Jakarta: Perempuan Mahardhika .

Rudnyckyj, D. 2018. Regimes of Precarity: Buruh, Karyawan, and the Politics of Labor Identity in Indonesia. In C. Hann, \& J. (. Parry, Industrial Labor on the Margins of Capitalism: Precarity, Class, and the Neoliberal Subject (pp. 155-179). New York: Berghahn Books.

Silvey, R., \& Elmhirst, R. 2003. Engendering Social Capital: Women Workers and RuralUrban Networks in Indonesia's Crisis. World Development Vol. XX, 1-15.

Sopranzetti, C. 2018. Owners of the Map: Motorcycle Taxi Drivers, Mobility, and Politics in Bangkok. Oakland: University of California Press.

Standing, G. 2011. The Precariat: The New Dangerous Class. London: Bloomsbury Academic.

Tambunan, T. 1998. Poverty Alleviation, Participation of Females and Empowerment of People in Indonesia. Humanomics Vol. 14 Iss 3, 76-106.

Tambunan, T. 2006. The Development of Industry and Industrialization Policy in Indonesia Since the New Governance Era to the Post-Crisis Period. Kadin Indonesia-JETRO.

Tjandraningsih, I. 2000. Gendered Work and Labour Control: Women Factory Workers in Indonesia. Asian Studies Review, Vol. 24, No. 2, 257-268.

Tjandraningsih, I. 2012. State-Sponsored Precarious Work in Indonesia. American Behavioural Scientist, 403-419.

Tsing, A. 2009. Supply Chains and the Human Condition. Rethinking Marxism: A Journal of Economics, Culture, \& Society, 148-176.

Warouw, N. 2008. Industrial Workers in Transition: Women's Experiences of Factory Work in Tangerang. In M. Ford, \& L. (. Parker, Women and Work in Indonesia (pp. 104-119). New York: Routledge.

Weber, M. 1946. Bureaucracy. In H. Gerth, \& C. Wright Mills, From Max Weber: Essays in Sociology (pp. 196-240). New York: Oxford University Press. 
Wolf, D. 1988. Female Autonomy, the Family, and Industrialization in Java. Journal of Family Issues, Vol. 9 No. 1, 85-107.

Yanagisako, S. 2002. Producing Culture and Capital: Family Firms in Italy. New Jersey: Princeton University Press. 